\section{ORIGIN OF THE NORTHERN RHODESIAN COPPER DEPOSITS}

The Geology of the Northern Rhodesian Copperbelt

Edited by Dr. F. Mendelsohn. Pp. xvi+523. (London : Macdonald and Co. (Publishers), Ltd., 1961.) 84s. net.

TN November 1902 W.C. Collier shot a roan antelope in the bush while prospecting near the Luanshya River : close to the body of the buck he found out. crops carrying copper and pegged a claim. Twentynine years later Roan Antelope became the first of the great Northern Rhodesian copper mines to come into production. To-day the Copperbelt supports a community of more than a quarter of a million and produces nearly one-fifth of the free world's copper.

Something of the scientific effort behind this great expansion is revealed by the twenty-three authors of the monograph under review. The majority are members of the geological staffs of the Anglo-American Corporation and Rhodesian Selection Trust, but there are also contributors from the British South Africa Company and Union Minière du Haut-Katanga. Since the ore deposits on the Copperbelt are almost wholly confined to a series of sediments of presumed Pre-Cambrian age, the Lower Roan Group of the Katanga System, the first necessity for exploration was a geological map showing the extent of these rocks. Its production was aided by aerial photography, and the recognition of individual deposits has been facilitated by a variety of geophysical and geochemical prospecting techniques.

Economic mineralization on the Copperbelt is concentrated in a zone about 100 miles long and up to 40 miles across. This is, however, but a fraction of the 500-mile arc of folded Katanga beds which stretches through Northern Rhodesia and the Congo into Angola, covering more than 80,000 square miles and forming one of the world's greatest base-metal provinces. Structurally, the Copperbelt is dominated by the north-west trending Kafue anticline, which brings up a central belt of pre-Katanga rocks and is flanked to the north-east by the Mufulira syncline and to the south-west by a series of en echelon downfolds on the flanks of which Bancroft, Nchanga, Chibuluma, Nkana and Roan Antelope Mines are situated. The ore-bodies occur in rock of varying lithology: in the Mufulira basin they are predomin. antly arenaceous, to the south-west more commonly argillaceous.

Lively controversy has surrounded the origin of the ores. On one hand their great lateral extent, their persistence at certain stratigraphical horizons, their intimate connexion with sedimentary features of the host rocks, the inferred relation of sulphide zoning to facies, the evidence that much of the mineralization is pre-folding, the absence of any obvious deep-seated source for the mineralizing solutions and the difficulty of envisaging movement of large volumes of such solutions for great distances through sediments of low permeability have suggested a sedimentary syngenetic origin. Lean copper deposits known to occur in the Pre-Katanga rocks have, it is suggested, been eroded, transported in solution to the basin of deposition and precipitated during the sedimentation of the Lower Roan Group. Subsequent redistribution has taken place during the folding and metamorphism of the sediments. On the other hand, there are many features more readily explained in terms of epigenetic hypogene mineralization. These include the relation of the deposits to the central region of the Katanga geosyncline and to fold axes, the presence of local mineralization in Pre-Katanga rocks immediately beneath ore-bodies in the Lower Roan Group, the geochemistry of the sediments, suggesting that they have undergone widespread metasomatism, and the inadequacy of the metamorphic temperatures capable of producing rocks of the greenschist facies to account for certain observed mineralogical features.

In many cases the evidence recorded from different mines is conflicting. At Roan Antelope ore has been proved over a strike length of about 7 miles and to a depth of nearly $4,000 \mathrm{ft}$. in a stratigraphically controlled ore-body with an average thickness of $25 \mathrm{ft}$. : at Nchanga it transgresses stratigraphical boundaries through more than $300 \mathrm{ft}$. of varied sediments. At Chibuluma and Roan Antelope the mineralization is unrelated to the folding : at Nkana South the ore-body is confined to the highly contorted and fissile portions of carbonaceous shales. At Mufulira mineralization is regarded as pre-dating slumping : at Mindola it appears to post-date faulting. It is scarcely to be wondered at that the various contributors fail to reach agreement as to the genesis of the ores, though more space is devoted to the sedimentary syngenetic theory than to any other. It is perhaps more surprising that no attempt is made to reconcile the puzzling association of criteria suggesting both syngenesis and epigenesis in some mechanism such as long-continued infiltration of ascending solutions into the basin of deposition as well as into the growing pile of sediments.

Supergene alteration persists to great depths on the Copperbelt, and some of the conflicting evidence may be a consequence of failure to recognize the full extent of secondary sulphide enrichment. More detailed investigation of this problem is evidently needed. Equally essential is the study of the relation of mineralization to both sedimentary and tectonic features in the base metal province of the Katanga geosyncline as a whole rather than in the small portion of it which forms the Copperbelt. Political factors, unfortunately, make this a more difficult task to-day than at any time in the past fifty years. When it can be undertaken it should prove both scientifically rewarding and commercially profitable. J. H. TAYLOR

\section{SCIENCE IN POETRY AND VERSE}

\section{A Book of Science Verse}

The Poetic Relations of Science and Technology. Selected by W. Eastwood. Pp. xvi+279. (London: Macmillan and Co., Ltd., 1961.) 21s. net.

THIS is a pleasant and successful anthology of the treatment of 'science'- the term is given a wide construction-in poetry and in verse. Mr. Eastwood, who is vice-principal of Reading Technical College, starts on an optimistic note. He points out in his introduction that "the separation of science and poetry does not go back much further than the late eighteenth century", that "poet and scientist are alike concerned with the ordering of experience, and to both the imagination is important" ... "a poetry which ignores science and its applications is, in the modern world, divorced from life" . . . "There is no future for a culture which cannot reconcile the poetic 